\title{
Chosen problems in forensic examining of signatures placed on paintings
}

\author{
MAREK LEŚNIAK \\ ORCID: 0000-0002-1204-0988 \\ University of Silesia, Katowice, Poland
}

\begin{abstract}
In the context of current forensic knowledge and practice, using the handwriting analysis method to examine a painter's signature does not give rise to any objections. It allows such an examination to be more transparent. The article presents a certain specificity which characterizes painter signatures. Such distinctions reveal themselves at various stages of analysis: examining the location of the questioned signature; qualifying examination of the questioned signature; determining the scope of handwriting features considered under the examination; determining the range of variability in handwriting characteristics in the comparative material; determining the degree of variability in the same characteristics in the questioned signature. The article also raises the issue of experts' competencies, particularly significant in examining painting signatures.
\end{abstract}

Keywords: handwriting analysis methods, analysis of signatures on paintings, experts' competencies

\section{Introduction}

There is no doubt that examining a painter's signature is among the elements essential for validating the authenticity of art pieces (if a work is signed, of course). The results of such an investigation are respected both 
in scholarly elaborations ${ }^{1}$ and in guides for art collectors. ${ }^{2}$ Therefore, its quality is of significant importance for forensic sciences and art markets.

The primary purpose of the article is to review the existing method of examining painters' signatures, and indicate issues that differ from other signature examinations. Nowadays, researchers implement handwriting analysis procedures to investigate painters' signatures. ${ }^{3}$ Based on descriptions from the Polish and international literature on the subject, ${ }^{4}$ it is possible to separate six stages of handwriting examinations.

1. Examining the location of the questioned signature.

2. Qualifying examination of the questioned signature.

3. Determining the scope of handwriting features considered under the examination.

4. Determining the range of variability in handwriting characteristics in the comparative material.

5. Determining the degree of variability in handwriting characteristics in the questioned signature.

6. Establishing whether the degree of variability described in item 5 is within the range described in item 4.

7. Drawing more far-reaching conclusions.

In the subsequent parts of this article, the stages are presented in the context of painter signature examination. The goal is to identify differences unique to this area of study. And finally, the article considers the question of the experts' qualifications. Who should analyze a painter's signature? Who does it in art market practice?

1 For example: O. Rybak-Karkosz, Badanie autentyczności grafiki artystycznej aspekty kryminalistyczne, Toruń 2020, pp. 248-260; D. Wilk, "Ekspertyza dzieł sztuki", [in:] Ekspertyza sądowa. Zagadnienia wybrane, eds. M. Kała, D. Wilk, J. Wójcikiewicz, Warszawa 2017, pp. 624-626.

2 M. Bryl, Rynek sztuki w Polsce. Poradnik dla kolekcjonerów i inwestorów, Warszawa 2016, p. 114.

3 T. Widła, Ekspertyza sygnatury malarskiej, Katowice 2016, pp. 29-33.

4 For example: E. Gruza, M. Goc, J. Moszczyński, Kryminalistyka, czyli o wspótczesnych metodach dowodzenia przestęstw, Warszawa 2020, pp. 493-499; T. Widła, "Badania dokumentów", [in:] Kryminalistyka, ed. J. Widacki, Warszawa 2018, pp. 274 275; R. Saferstein, Criminalistics: An introduction to forensic science, Upper Saddle River, NJ 2007, pp. 498-501. 


\section{Examing the location of a questioned signature}

At this stage of signature examination, experts search for any signs of changing the substrate of the signature or its fragments. Finding such changes in a questioned document usually indicates counterfeiting. In works of art, however, creators often change the work before they are satisfied enough with its realization. Such changes may occur in different parts of the original piece, including the location of the signature. And finally, the signing was generally associated with finishing the artwork. ${ }^{5}$ We cannot rule out the situation that a painter has corrected their signature.

Independent of chemists and art restorers, handwriting experts should exam the surface of the questioned art piece in the signature area as well as around it. Such non-destructive testing is based on observation using a professional magnifying device. For the most part, such a procedure is identical to a non-damaging technical document examination. ${ }^{6}$ It includes exposing the signature to light under various conditions - besides microscopic examination in visible light, it may involve using filters with different light wavelengths, visible luminescence excited by ultraviolet or infra-red (including visible fluorescence excited by ultraviolet radiation).

For purposes of forensic technical document examination, experts often use video spectral comparators, which allow a comprehensive optical analysis. Experts may also use the device for non-destructive examination of artwork, but due to its size it allow an expert to examine only relatively small paintings. Therefore examining artworks demands preparing a professional test site.

This stage of analysis is conducted in the presence of the artwork's owner (owners). When examining other kinds of handwriting, an expert deals with the original writing on their own. Here, however, the owner watches the expert's actions. In this way, the expert may avoid risky situations, since in Poland, handwriting experts generally are not insured. In the case of artwork with disputed authenticity, it is not easy to evaluate the cost of the applicable premium rate. Supposedly it would

5 T. Widła, Świat sygnatur, Katowice 2017, p. 19.

6 R. Cieśla, The technical examination of documents within the scope of Polish evidence law, Wrocław 2006, pp. 131-146. 
be beyond the the expert's financial capacity. For this reason, the artwork is under the control of its owners during all analyses. It is very often the only stage when experts deal with the original work.

\section{Qualifying examination}

The second stage includes the qualifying examination of a questioned painter signature. An expert must determine if the signature is suited for handwriting examination in general, depending on its graphic content and imaging performance.

The more letters the signature includes, the greater the chance of carrying out an effective analysis. Different types of letters (capital and lowercase) allow an expert to extend the examination range. There is a possibility to study graphic signs other than letters and figures.

In paintings (particularly oil ones) the signature quality may be lacking due to a thick varnish layer. The signature may have been damaged during a restoration. In such a situation, signature examination may be very limited or impossible.

\section{Determining the scope of handwriting features considered under the examination}

There is no one commonly accepted range of all handwriting characteristics that must be taken into consideration in every handwriting analysis. However, the catalogs of features suggested in professional literature are very similar to each other. ${ }^{7}$ Experts may use only some of them when analyzing signatures located on paintings (for example, due to the properties of a particular substrate, tool, paint, or pastel). In related professional Polish literature, Tadeusz $\mathrm{Widła}^{8}$ presents three groups of characteristics of signature analysis:

7 For example: O. Hilton, Scientific examination of questioned documents, New York 1984, pp. 153-171; R.A. Huber, A.M. Headric, Handwriting identification: Facts and fundamentals, Boca Raton, FL 1999, pp. 89-139.

8 T. Widła, Ekspertyza..., p. 235. 
- features of the area of the inscription - the placement of the graphism (signature/date) on the surface of the painting, spacing between letters, spacing between words, spacing between lines, the slant of axes of letters and words as well as the form of angles between strokes, the sizes of characters, the proportions between their hights and the shapes formed by the contouring of extremities;

- descriptive features (construction features) with concern the shaping of the characters - the connectedness between characters (the number of items created with one continuous movement of the writing tool), the forming the majuscule and minuscule, the rounding of the tops and poligrammes, the rounding of loops, the attachment of lateral elements to oval and to vertical elements, the forming and placement of diacritcal signs, etc.;

- content and language features - the presence of mistakes in wording and spelling, the presence of foreign words and interferences of foreign languages to the painter's residence in areas these languages were spoken and other linguistic phenomena.

The range of characteristics (i.e. elements such as: the type of signature, the number of lines, words, and letters, the type of letters and handwriting tools, the covering material) considered in the analysis of a particular signature depends on its graphic context. Handwriting characteristics divide into quantitative and qualitative traits. The measurement of the former is less subjective; ${ }^{9}$ in turn, the latter better represent the complexity of handwriting. Every examination should cover both quantitative and qualitative features.

The list of handwriting characteristics is constantly expanding. Some of the new traits were discovered thanks to computer algorithms. ${ }^{10}$ The software used in Polish practice only supports the expert's decision and does not substitute an expert. It facilitates the measurement of already known handwriting features or allows an expert to measure new ones. It may be used for examing painting signatures, too. Some researchers will strive to develop softwares designed specifically for analysing painters' signatures. ${ }^{11}$ In Poland, such programs are not yet used in practice.

${ }^{9}$ For example: M. Leśniak, O. Rybak, T. Widła, "Badania cech grafometrycznych sygnatur Teodora Axentowicza w pracach wykonanych techniką olejną", [in:] Zagadnienia dowodu z ekspertyzy dokumentów, ed. R. Cieśla, Wrocław 2017, pp. 266-272.

${ }^{10} \mathrm{M}$. Goc, Wspótczesny model ekspertyzy pismoznawczej. Wykorzystanie nowych metod i technik badawczych, Warszawa 2015, pp. 235-318.

${ }^{11}$ K. Kapłon, R. Ptak, "Wspomagana komputerowo analiza podpisu na dziele malarskim na przykładzie sygnatur Władysława Podkowińskiego", [in:] Zagadnienia dowodu..., pp. 203-209. 


\section{Determining the range of variability in handwriting characteristics in the comparative material}

Comparative material should only comprise artworks with known provenance and signatures of undisputed origin. However, even then the expert should conduct a qualifying examination. After all, it cannot be excluded that an artwork (or at least the signature placed on it) generally considered to be authentic is fake. The expert may also reject some of the comparative signatures independently of the artworks' provenance - provided that they justify such a decision in their report, of course. The expert should name the signatures used as comparative materials. It is a significant element of their report because different comparative materials may cause divergences between expert opinions. This solution may allow recipients to find the cause of the contradiction.

The signatures should reflect the signer's habit and the entire scope of their graphical changeability. It demands using non-questioned signatures from all periods of the painter's artistic activity. When the creation time of the questioned signature is known, comparative material should include signatures that originated around the same period. Suppose a disputed signature is combined with other words or figures (for example, painters sometimes put the date of creation, the place of production, and other notations near the signature). In that case, comparative material should, if possible, include similar inscriptions (this also concerns handwritings created outside of artworks).

When a handwriting expert acts as an expert witness in Polish court, procedural decision-makers (police officers, prosecutors, judges) are responsible for providing the expert with proper comparative material. In examinations made for non-public entities, this obligation falls on the contracting authority. This can be different for examing signatures placed on paintings - an expert may search for comparative signatures in the public space. They most commonly find such samples in three kinds of sources. First, they could watch the signature and photograph it in public museums and galleries. Additionally, for some painters, extended catalogs are created, incorporating high-quality reproductions of many 
artworks with separate pictures of signatures. ${ }^{12}$ There are also multiple websites which provide high-quality photographs of paintings and signatures, usually made by public museums and galleries (and often created under the national art digitalization programs), and private art dealers (it allows potential buyers to watch art pieces subsequently offered at auctions). But sometimes, private art collectors own most paintings by a particular painter and prohibit the public (and experts) from accessing them. It reduces the number of comparative signatures and thus hampers examinations of disputed signatures.

After selecting the comparative material and evaluating its quality, an expert measures the quantitative characteristics with proper devices and determines values of qualitative traits. The expert takes into consideration the scope of handwriting features chosen in the previous stage. They assess the range of changeability, considering the features separately.

\section{Determining the range of variability in handwriting characteristics in the questioned signature}

The collection of measured or estimated features is the same as during the comparative signatures analysis stage. Experts assess the range of values (variability) on every characteristic separately. In the case of a painter's signature, they usually have limited access to the signature. Contrary to classical handwriting analysis, here the expert measures and determines the range of handwriting traits based on photographed signatures instead of the original ones.

Sometimes the area surrounding the examined signature greatly complicates examination. The presence of other background elements and colors may cover parts of the signature. An expert may use software to reveal sequence of lines from the signature placed on a painting. In Poland, experts often use software that allows them to extract lines of the signature from the background. ${ }^{13}$

12 For example: Maksymilian Gierymski (1846-1874). Katalog dziel zebranych, ed. A. Krypczyk-de Barra, Kraków 2019.

13 The example using such a software toward a signature placed on an artwork: M. Leśniak et al., "Badania sygnatur Markusa Lüpertza", [in:] Problematyka dowodu z dokumentu, ed. R. Cieśla, Wrocław 2019, p. 249. 


\section{Establishing whether the degree of variability described in item 5 is within the range described in item 4}

After determining the range of variability in particular handwriting features both in the comparative material and the disputed signature, an expert can investigate whether the values of the disputed signature are located within the variability range of the comparative material. An expert may come to three kinds of conclusions: the degree of variability in the examined comparative signatures includes values of the disputed signature; the degree of variability in the examined comparative signatures does not include values of the disputed signature; and, the expert does not find explanations to the observed differences, the degree of variability in the examined comparative signatures does not include values of the disputed signature but the expert may find reasons for the observed differences. These expert decisions are transparent (susceptible to being checked by another expert).

In regards to the third conclusion type, what explanations may an expert find for the observed differences? They may look for answers within the outcomes of published scientific empirical research. The differences may be pathological in nature - professional literature presents many studies on the influence of particular disorders or substance abuse on handwriting performances. ${ }^{14}$ There are also some occasional factors which may impact the signature, such as environmental temperature or an unusual type of surface.

\section{Drawing more far-reaching conclusions}

In Polish practice, experts formulate more far-reaching conclusions than those described in the previous section. They state whether it was the same person who wrote the comperative signatures and the disputed signature (compared signatures are manifestations of the same formed

14 For example: M. Całkiewcz, Kryminalistyczne badania patologicznego pisma ręcznego, Warszawa 2009; T. Widła, "Z problematyki patologii pisma ręcznego", [in:] Kryminalistyka i nauki sądowe wobec przestępczości, ed. H. Kołecki, Poznań 2008, pp. 139-177. 
habit). This kind of conclusion is based on the expert's experience and refers to subjective probability.

According to empirical studies, the accuracy of handwriting expert opinions remains between $45 \%$ and $95 \%{ }^{15}$ The lowest accuracy is connected to disguised handwritings, in which "the person has made a deliberate attempt to remove or to modify all or some of his or her regular writing habit."16 Fortunately for analysing signatures placed on paintings, this kind of signature is not mentioned in the context of disguised handwriting. ${ }^{17}$ In the case of spontaneous writing analysis, the accuracy of correctly-executed handwriting analyses reaches $90 \% .{ }^{18}$ It should be noted that, similarly to classical handwriting examination, an expert may decide that the signature placed on a painting is inauthentic without describing the manner of forgery. ${ }^{19}$

\section{Competencies of experts}

Many different kinds of specialists speak about the authenticity of painters' signatures in the art market practice. ${ }^{20}$ These include art historians, art restorers, members of the painters' families (sometimes a relationship with the painter appears to be the only requirement for a position of authority regarding the painting's and signature's authenticity), employees of art museums and art galleries, antiquarians, and others. It should be emphasized that excellent knowledge of the painter's life and creative work does not give enough competence to conduct a handwriting examination of the painter's signatures. The analysis of signatures demands knowledge and skills from the area of forensic handwriting examination. The expert does not need to be an enthusiast of the painter chosen as the investigation subject - they should have the competencies

15 M. Leśniak, Wartość dowodowa opinii pismoznawczej, Pińczów 2012, pp. 292-296.

16 A. Koziczak, Autofatszerstwo, Warszawa 2020, p. 31 [trans. ML].

17 Ibid.

18 M. Leśniak, Wartość..., p. 293.

19 T. Tomaszewski, "Oczywiste fałszerstwo, nieoczywista metoda jego dokonania”, Człowiek i Dokumenty 57, 2020, pp. 40-47.

20 N. Fryderek, "Eksperci rynku sztuki w Polsce - sytuacja prawna i praktyka", [in:] Rynek sztuki aspekty prawne, Warszawa 2011, pp. 108-118. 
necessary for handwriting analysis, as well as access to proper equipment (including a professional test bench). Moreover, they should be aware of the specificities unique to this type of signature (such as the use of particular painting tools, paints, pastels, crayons).

However, sometimes even regular handwriting experts may not possess sufficient skill to examine not only painters' signatures, but also handwriting in general. There are expert witnesses in Poland, which means persons present on the 45 lists administered by presidents of regional courts (under the Regulation of the Minister of Justice of 24 January 2005 on expert witnesses ${ }^{21}$ ). According to the regulation ( $\left.§ 12\right)$, a person to be appointed as an expert witness should have, among other qualifications, theoretical and practical knowledge of a particular field of science, technology, arts, crafts, or other skills relevant to the court appointment which should guarantee proper performance of their duties as an expert. The responsibility of verifying the experts' knowledge and experience before putting them on one of the the lists rests with the president of a regional court. The existing regulations and practices do not guarantee the presence of persons with the highest professional qualifications on the expert witness list. ${ }^{22}$ However, many expert witnesses in the field of handwriting are highly qualified.

To obtain a valuable expert opinion on the authenticity of painters' signatures, art market participants should verify the person's qualifications before ordering analysis. The best way to do it would include becoming familiar with analyses performed in prior cases. However, an expert cannot reveal their report independent of the ordering party, which decides whether to make the report public. The most effective solution would be to create a public institution whose purpose would be monitoring the quality of expert assessment in the art market. The institution could cooperate with art market participants and disseminate information about "good practices" in other authenticity investigations (including painters' signature examination).

21 Dz.U. (Journal of Laws) of 2005, no. 15, item 133.

22 S. Ławrentjew, Opiniowanie pismoznawcze w sprawach testamentowych, Toruń 2019, pp. 171-183. 


\section{Conclusion}

Managing the quality of the analysis requires setting and sustaining certain standards. Treating painters' signature analysis as a kind of forensic handwriting examination allows using criteria from forensic sciences literature. If an expert maintains standards, their opinion may be subject to other experts' control. Forensic handwriting examination standards oblige experts to justify their conclusion correctly. Of course, experience may play a vital role in drawing conclusions, but it cannot substitute rational arguments. Relying only on somebody's experience is not scientific because it is something another expert cannot verify. It may happen that different experts reach contrary conclusions. Only after gaining insight into the experts' arguments can the art market participants know the essence of their inconsistency. It also allows evaluation when the submitted analysis of the painter's signature is deemed unprofessional.

Painters' signatures are among the fundamental pieces of information about the provenance of artworks. However, art market participants should keep in mind that the masterpiece and its signature belong to different spheres. It is possible to encounter four situations: ${ }^{23}$ both the signed artwork and its signature are authentic, or both are fake; the painting is authentic, but the signature is not; the painting is not authentic, but the signature is. Therefore, the authenticity or inauthenticity of the signature does not determine the authenticity or falsification of the submitted painting.

\section{Bibliography}

Bryl M., Rynek sztuki w Polsce. Poradnik dla kolekcjonerów i inwestorów, Warszawa 2016. Całkiewcz M., Kryminalistyczne badania patologicznego pisma ręcznego, Warszawa 2009. Cieśla R., The technical examination of documents within the scope of Polish evidence law, Wrocław 2006.

Fryderek N., "Eksperci rynku sztuki w Polsce - sytuacja prawna i praktyka", [in:] Rynek sztuki aspekty prawne, Warszawa 2011.

Goc M., Wspótczesny model ekspertyzy pismoznawczej. Wykorzystanie nowych metod i technik badawczych, Warszawa 2015.

23 T. Widła, "Autentyczność sygnatury a autentyczność dzieła sztuki”, [in:] Meandry ochrony dziedzictwa narodowego. Aspekty prawnokarne i kryminalistyczne, eds. M. Sabaciński, M. Trzciński, Warszawa 2019, pp. 175-179. 
Gruza E., Goc M., Moszczyński J., Kryminalistyka, czyli o współczesnych metodach dowodzenia przestęstw, Warszawa 2020.

Hilton O. , Scientific examination of questioned documents, New York 1984

Huber R.A., A.M. Headric, Handwriting identification: Facts and fundamentals, Boca Raton, FL 1999.

Kapłon K., R. Ptak, "Wspomagana komputerowo analiza podpisu na dziele malarskim na przykładzie sygnatur Władysława Podkowińskiego", [in:] Zagadnienia dowodu z ekspertyzy dokumentów, ed. R. Cieśla, Wrocław 2017.

Koziczak A., Autofatszerstwo, Warszawa 2020.

Leśniak M., Wartość dowodowa opinii pismoznawczej, Pińczów 2012

Leśniak M. et al., "Badania sygnatur Markusa Lüpertza", [in:] Problematyka dowodu z dokumentu, ed. R. Cieśla, Wrocław 2019.

Leśniak M., O. Rybak, T. Widła, "Badania cech grafometrycznych sygnatur Teodora Axentowicza w pracach wykonanych techniką olejną", [in:] Zagadnienia dowodu z ekspertyzy dokumentów, ed. R. Cieśla, Wrocław 2017.

Ławrentjew S., Opiniowanie pismoznawcze w sprawach testamentowych, Torun 2019. Maksymilian Gierymski (1846-1874). Katalog dziet zebranych, ed. A. Krypczyk-de Barra, Kraków 2019.

Rybak-Karkosz O., Badanie autentyczności grafiki artystycznej - aspekty kryminalistyczne, Toruń 2020.

Saferstein R., Criminalistics: An introduction to forensic science, Upper Saddle River, NJ 2007.

Tomaszewski T., "Oczywiste fałszerstwo, nieoczywista metoda jego dokonania", Czlowiek i Dokumenty 57, 2020.

Widła T., "Autentyczność sygnatury a autentyczność dzieła sztuki”, [in:] Meandry ochrony dziedzictwa narodowego. Aspekty prawnokarne i kryminalistyczne, eds. M. Sabaciński, M. Trzciński, Warszawa 2019.

Widła T., "Badania dokumentów", [in:] Kryminalistyka, ed. J. Widacki, Warszawa 2020.

Widła T., Ekspertyza sygnatury malarskiej, Katowice 2016.

Widła T., Świat sygnatur, Katowice 2017.

Widła T., "Z problematyki patologii pisma ręcznego", [in:] Kryminalistyka i nauki sq̨dowe wobec przestępczości, ed. H. Kołecki, Poznań 2008.

Wilk D., "Ekspertyza dzieł sztuki", [in:] Ekspertyza sqdowa. Zagadnienia wybrane, eds. M. Kała, D. Wilk, J. Wójcikiewicz, Warszawa 2017. 